\title{
PEMODELAN TINGKAT PENGHUNIAN KAMAR HOTEL DI KENDARI DENGAN TRANSFORMASI WAVELET KONTINU DAN PARTIAL LEAST SQUARES
}

\author{
Margaretha Ohyver; Herena Pudjihastuti \\ Mathematics and Statistics Department, School of Computer Science, Binus University \\ Jln. K.H. Syahdan No. 9 Palmerah, Jakarta Barat 11480 \\ mohyver@binus.edu
}

\begin{abstract}
Multicollinearity and outliers are the common problems when estimating regression model. Multicollinearitiy occurs when there are high correlations among predictor variables, leading to difficulties in separating the effects of each independent variable on the response variable. While, if outliers are present in the data to be analyzed, then the assumption of normality in the regression will be violated and the results of the analysis may be incorrect or misleading. Both of these cases occurred in the data on room occupancy rate of hotels in Kendari. The purpose of this study is to find a model for the data that is free of multicollinearity and outliers and to determine the factors that affect the level of room occupancy hotels in Kendari. The method used is Continuous Wavelet Transformation and Partial Least Squares. The result of this research is a regression model that is free of multicollinearity and a pattern of data that resolved the present of outliers.
\end{abstract}

Keywords: multicollinearity, outlier, partial least squares, wavelet

\begin{abstract}
ABSTRAK
Multikolinier dan outlier merupakan kasus yang sering terjadi ketika membuat pemodelan dengan menggunakan regresi. Multikolinier menyebabkan kesulitan dalam memisahkan pengaruh masing-masing variabel bebas terhadap variabel respon. Outlier menyebabkan tidak terpenuhinya asumsi normalitas dalam regresi. Kedua kasus ini terjadi dalam data tingkat penghunian kamar hotel di Kendari. Tujuan dari penelitian ini adalah menemukan model untuk data tersebut yang bebas dari multikolinier dan outlier serta menentukan faktor-faktor yang berpengaruh terhadap tingkat penghunian kamar hotel di Kendari. Metode yang digunakan adalah Transformasi Wavelet Kontinu dan Partial Least Squares. Berdasarkan penelitian yang dilakukan diperoleh model regresi yang sudah bebas dari multikolinear. Selain itu diperoleh pola data dimana outlier sudah cukup teratasi.
\end{abstract}

Kata kunci: multikolinier, outlier, partial least squares, wavelet 


\section{PENDAHULUAN}

Pemodelan dengan regresi telah banyak digunakan. Mulai dari bidang sosial, ekonomi, kimia, kesehatan, dan sebagainya. Dengan model regresi yang dihasilkan, dapat diketahui variabel-variabel yang secara signifikan mempengaruhi variabel yang lain. Untuk memperoleh suatu model regresi yang baik maka model tersebut harus memenuhi asumsi-asumsi yang berlaku, antara lain adalah asumsi normalitas, homoskedastisitas, dan autokorelasi. Jika asumsi-asumsi yang ada dalam regresi telah terpenuhi maka ada satu hal lagi yang perlu diperhatikan yaitu adanya outlier dan pengamatan berpengaruh pada data. Sehingga sebelum menerapkan metode-metode statistika pada data maka sangat penting untuk dilakukan pendeteksian outlier (Derquenne, 1993).

Identifikasi outlier dan pengamatan berpengaruh pada model regresi didasarkan pada asumsi bahwa model regresi yang diperoleh sudah tepat. Hal ini berarti model regresi yang telah dipilih telah cukup menggambarkan hubungan antara variabel respon dan variabel independen. Jika model regresi telah ditentukan, sebagian besar data seharusnya mendekati garis regresi atau hyperplane. Titik-titik data yang berada jauh dari garis regresi atau hyperplane mungkin bukan titik-titik data ideal bagi model yang dipilih dan dapat diidentikasikan sebagai outlier. Berbagai komunitas scientific mempunyai definisi yang berbeda-beda mengenai outlier. efinisi tersebut ada yang berdasarkan distribusi, jarak, dan densitas (Zhu et al, 2011). Konsekuensinya adalah pendekatan yang diberikan berbeda-beda pula. Sesuatu yang menurut seseorang adalah outlier bisa menjadi bukan outlier bagi orang lain.

Karena adanya outlier dapat mengganggu pemodelan maka perlu dilakukan suatu langkah yang disebut pra-pemrosesan data. Langkah ini dilakukan dengan cara mentransformasi data yang akan digunakan. Hasil yang diperoleh dari transformasi data ini diharapkan dapat mengatasi outlier yang ada. Salah satu transformasi yang dapat digunakan adalah transformasi wavelet. Transformasi wavelet telah banyak digunakan di berbagai penelitian. Antara lain adalah penggunaan TWK untuk menghasilkan spectograms yang menunjukkan frekuensi suara (Lang dan Forinash, 1998), analisis deret waktu chaotic dengan wavelet (Murguia dan Campos-Canton, 2005), dan penaksiran koefisien wavelet dalam regresi nonparametrik (Antoniadis, Bigos, dan Sapatinas, 2001).

Terdapat beberapa jenis mother wavelet yang dapat digunakan dalam transformasi wavelet. Antara lain adalah Haar, Gaussian, Mexican Hat, dan Morlet. Untuk menentukan mother wavelet yang digunakan dapat dilihat pada sifat-sifat sinyal dan kebutuhan dari peneliti (Addison, 2002), atau dengan mencoba semua mother wavelet kemudian dilihat mother wavelet yang sesuai dengan data (Chen, Hu, Shao \& Qingde, 2004).

Artikel ini akan membahas penggabungan transformasi wavelet dengan metode pemodelan statistika, yaitu Partial Least Squares (PLS). Mother wavelet yang digunakan adalah Haar wavelet. Yang melatarbelakangi digunakannya penggabungan ini adalah adanya outlier dan multikolinear pada data yang digunakan, yaitu data pengunjung hotel di kota Kendari. Data ini telah digunakan pada beberapa penelitian dengan hasil sebagai berikut. Pertama, terdapat outlier pada data tersebut. Kedua, terdapat multikolinear. Ketiga, untuk mengatasi adanya outlier dan multikolinear digunakan metode transformasi logaritma natural dan PLS. Berdasarkan hasil ketiga diketahui bahwa nilai $\mathrm{R}^{2}$ yang diperoleh masih belum cukup baik. Oleh karena itu digunakanlah transformasi wavelet sebagai metode pra-pemrosesan data dengan tujuan memperoleh nilai $\mathrm{R}^{2}$ yang baik. 
Tabel 1 Variabel Penelitian

\begin{tabular}{llc}
\hline No & Nama variabel & Simbol \\
\hline 1. & Usia hotel/penginapan & $\left(X_{1}\right)$ \\
2. & Tarif minimal hotel/penginapan & $\left(X_{2}\right)$ \\
3. & Tarif maksimal hotel/penginapan & $\left(X_{3}\right)$ \\
4. & Fasilitas yang dimiliki hotel atau penginapan & $\left(X_{4}\right)$ \\
5. & Jumlah tenaga kerja yang dimiliki hotel/penginapan & $\left(X_{5}\right)$ \\
6. & Jumlah kamar yang dimiliki hotel/penginapan & $\left(X_{6}\right)$ \\
7. & Jumlah tempat tidur yang dimiliki hotel/penginapan & $\left(X_{7}\right)$ \\
8. & Jumlah tamu & $(Y)$ \\
\hline
\end{tabular}

\section{METODE}

Data yang akan digunakan adalah data sekunder. Data ini diperoleh dari katalog Badan Pusat Statistik (BPS) Sultra tahun 2011. Ada 90 hotel/penginapan yang menjadi sampelnya. Hotel/penginapan tersebut berada di wilayah Kendari. Variabel-variabel yang digunakan terdapat pada Tabel 1, dengan 7 (tujuh) variabel bebas $(X)$ dan 1 (satu) variabel tak bebas atau variabel respon $(Y)$. Metode yang akan digunakan adalah Transformasi Wavelet Kontinu (TWK) dan Partial Least Square (PLS). Mother wavelet yang akan digunakan adalah Haar wavelet. Adapun tahapan-tahapan yang harus dilakukan adalah sebagai berikut. Pertama, melakukan transformasi wavelet kontinu terhadap 90 pengamatan dengan melibatkan hanya variabel bebas. Kedua, membentuk model regresi untuk data hasil transformasi wavelet kontinu.

Teori wavelet adalah suatu konsep yang relatif baru dikembangkan. Wavelet pertama kali diperkenalkan oleh Alfred Haar pada tahun 1909. Kata "wavelet" sendiri diberikan oleh Jean Morlet dan Alex Grossmann di awal tahun 1980-an, dan berasal dari bahasa Perancis, ”ondelette” yang berarti gelombang kecil. Kata "onde" yang berarti gelombang kemudian diterjemahkan ke bahasa Inggris menjadi "wave", lalu digabung dengan kata aslinya sehingga terbentuk kata baru "wavelet".

Suatu fungsi $\psi(t)$ didefinisikan sebagai wavelet jika memenuhi:

$$
\begin{aligned}
& \int_{-\infty}^{\infty} \psi(t) d t=0 \\
& \int_{-\infty}^{\infty} \psi^{2}(t) d t=1
\end{aligned}
$$

(a)

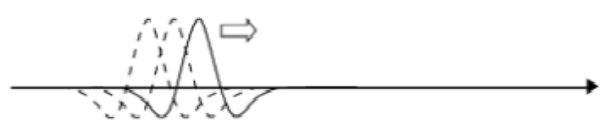

(b)

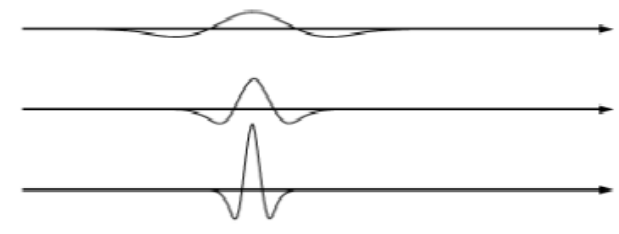

Gambar 1 (a) Translasi dan (b) Dilatasi (Addison, 2002) 
Jika ada fungsi wavelet $\psi(t)$, yang disebut mother wavelet, maka dapat dibangkitkan sekumpulan fungsi lain yang akan menjadi fungsi basis dalam suatu ruang fungsi $L^{2}(R)$ dengan cara dilatasi dan translasi. Pada Gambar 1 (a) dan (b) dapat dilihat contoh translasi dan dilatasi wavelet.

$$
\psi_{a, b}(t)=\frac{1}{\sqrt{|a|}} \psi\left(\frac{t-b}{a}\right), a \neq 0, a, b \in R
$$

$a$ merupakan parameter dilatasi atau skala yang mengukur derajat pemampatan atau skala. Jika $|a|<1$ maka wavelet akan memampat, sedangkan jika $|a|>1$ maka wavelet akan melebar. $b$ merupakan parameter translasi yang menentukan lokasi waktu dari wavelet.

Suatu fungsi atau sinyal dapat ditransformasi ke dalam suku-suku wavelet. Transformasi ini dikenal dengan transformasi wavelet. Atau secara matematik, transformasi wavelet adalah suatu konvolusi antara fungsi wavelet dengan sinyal (Addison, 2002). Ada dua jenis transformasi wavelet, yaitu transformasi wavelet diskrit (TWD) dan transformasi wavelet kontinu (TWK). Perbedaan diantara keduanya adalah pada nilai $a$ dan $b$, yaitu dengan membatasi $a$ dan $b$ hanya pada nilai-nilai diskrit: $a=a_{0}^{m}, b=n b_{0} a_{0}^{m}, m, n \in Z$, dan $a_{0}>1, b_{0}>0$ (Daubechies, 1992).

TWK:

$C_{f}(a, b)=\frac{1}{\sqrt{|a|}} \int_{-\infty}^{\infty} f(t) \psi^{*}\left(\frac{t-b}{a}\right) d t$

TWD:

$$
C_{f}(a, b)=a_{0}^{-m / 2} \int_{-\infty}^{\infty} f(t) \psi\left(a_{0}^{-m} t-n b_{0}\right) d t
$$

Banyak kejadian di dunia berhubungan dengan sinyal yang dapat dianalisis. Sebagai contoh, getaran gempa, suara manusia, getaran mesin, data finansial, dan musik. Untuk menganalisis sinyalsinyal ini, dapat digunakan analisis wavelet. Seperti yang dikemukakan sebelumnya bahwa ada dua jenis transformasi wavelet, yaitu TWD dan TWK. Yang membedakan antara keduanya adalah skala dan translasinya. Pada TWK, transformasi dapat dilakukan pada setiap bilangan skala dan translasi. Persamaan (4) dapat dituliskan dalam bentuk:

$$
C_{f}(a, b)=\int_{-\infty}^{\infty} f(t) \psi_{a, b}^{*}(t) d t
$$

atau

$$
C_{f}(a, b)=\left\langle f(t), \psi_{a, b}(t)\right\rangle
$$

dengan $C_{f}(a, b)$ adalah koefisien wavelet dalam berbagai skala dan $f(t)$ adalah data yang akan ditransformasi. Tanda “*” menyatakan kompleks konjugate dari fungsi wavelet. Akan tetapi kompleks konjugate ini hanya diperlukan apabila mother wavelet yang digunakan adalah wavelet kompleks.

Metode Partial Least Squares (PLS) merupakan salah satu metode yang dapat digunakan untuk mengatasi masalah multikolinier. PLS merupakan perpaduan antara principal component analysis (PCA) dan regresi linier ganda (Abdi, 2003). PCA merupakan suatu metode untuk mereduksi 
banyaknya peubah bebas menjadi beberapa peubah baru yang dapat menjelaskan dengan baik keragaman data dan peubah baru tersebut tidak berkorelasi. Untuk membentuk hubungan antara peubah respon dan peubah bebas, PLS membentuk peubah bebas yang baru yang disebut faktor, peubah laten, atau komponen, dimana masing-masing komponen yang terbentuk merupakan kombinasi linier dari peubah-peubah bebas. Tujuan utama dari PLS adalah membentuk komponen yang dapat menangkap informasi dari peubah bebas untuk menduga peubah respon (Hoskuldsson dalam Garthwaite, 1994).

Jika $(n<p)$, maka metode metode kuadrat terkecil tidak dapat digunakan (Naes, Isaksson, dkk., 2002). Hal ini dikarenakan matriks $\mathbf{X}^{\mathbf{T}} \mathbf{X}$ singular. Sebaliknya, PLS dapat digunakan untuk kasus $(n<p)$. Regresi PLS didasarkan pada dekomposisi komponen:

$$
\begin{aligned}
& \mathbf{Y}=\mathbf{T} \mathbf{Q}^{\prime}+\mathbf{F} \\
& \mathbf{X}=\mathbf{T} \mathbf{P}^{\prime}+\mathbf{E}
\end{aligned}
$$

dengan $\mathbf{T}$ adalah matriks komponen, $\mathbf{P}$ dan $\mathbf{Q}$ adalah matriks loading $X$ dan $Y, \mathbf{E}$ dan $\mathbf{F}$ adalah vektor error (Boulesteix dan Strimmer, 2006).

Metode PLS dapat dipandang sebagai metode yang membentuk matriks komponen $\mathbf{T}$ sebagai transformasi linier dari $\mathbf{X}$.

$$
\mathbf{T}=\mathbf{X W}
$$

dengan $\mathbf{W}$ adalah matriks weights (bobot). Persamaan (10) dapat dituliskan sebagai berikut.

$$
\begin{aligned}
& T_{1}=w_{11} x_{1}+w_{21} x_{2}+\cdots+w_{p 1} x_{p} \\
& T_{2}=w_{12} x_{1}+w_{22} x_{2}+\cdots+w_{p 2} x_{p} \\
& \vdots \\
& T_{c}=w_{1 c} x_{1}+w_{2 c}+\cdots+w_{p c} x_{p}
\end{aligned}
$$

Komponen-komponen kemudian digunakan untuk pendugaan, dengan menggantikan $\mathbf{X}$. Sehingga diperoleh penduga kuadrat terkecil:

$$
\hat{\mathbf{Q}}^{\prime}=\left(\mathbf{T}^{\prime} \mathbf{T}\right)^{-1} \mathbf{T}^{\prime} \mathbf{Y}
$$

\section{HASIL DAN PEMBAHASAN}

Sulawesi Tenggara (Sultra) merupakan salah satu provinsi di Indonesia. Sultra ditetapkan sebagai daerah otonom berdasarkan Perpu No. 2 tahun 1964 juncto UU No. 13 Tahun 1964. Pada awalnya terdiri atas empat kabupaten dan kini setelah pemekaran Sultra telah mempunyai sepuluh kabupaten dan dua kota, di mana ibukotanya terletak di kota Kendari. Tanggal 27 April 1964 merupakan hari lahir Provinsi Daerah Tingkat I Sultra (Biro Humas Sultra, 2011). Sultra termasuk dalam provinsi berkembang. Hal ini terlihat dari pertumbuhan ekonomi daerah yang cukup tinggi, yaitu di atas 8\%. Angka kemiskinan di Sultra turun dari 21\% menjadi 14,6\% pada tahun 2011 (Investor Daily Indonesia, 2012). Salah satu faktor yang dapat dianggap berperan adalah adanya perkembangan dalam sektor jasa perhotelan. Berdasarkan data resmi Dinas Tenaga Kerja dan 
Transmigrasi Sultra per Desember 2011 menunjukkan bahwa sektor perhotelan dan rumah makan di Sultra telah menyerap 8791 tenaga kerja lokal (Media Sultra, 2011).

Pada Gambar 2 terdapat perkembangan jumlah hotel di Sultra. Dapat dilihat bahwa sejak tahun 2005, jumlah hotel terus bertambah. Hal ini menunjukkan bahwa persaingan dapat terjadi antar pemilik hotel. Jika para pemilik hotel ingin memperoleh jumlah pengunjung yang banyak maka perlu diketahui faktor-faktor yang mempengaruhinya.

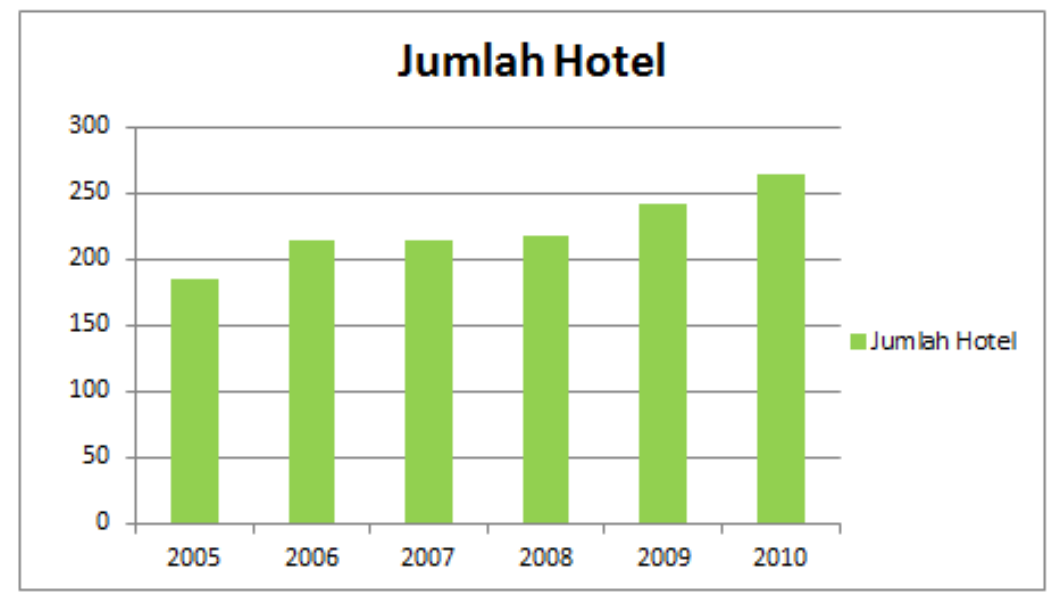

Gambar 2 Perkembangan Jumlah Hotel di Sultra

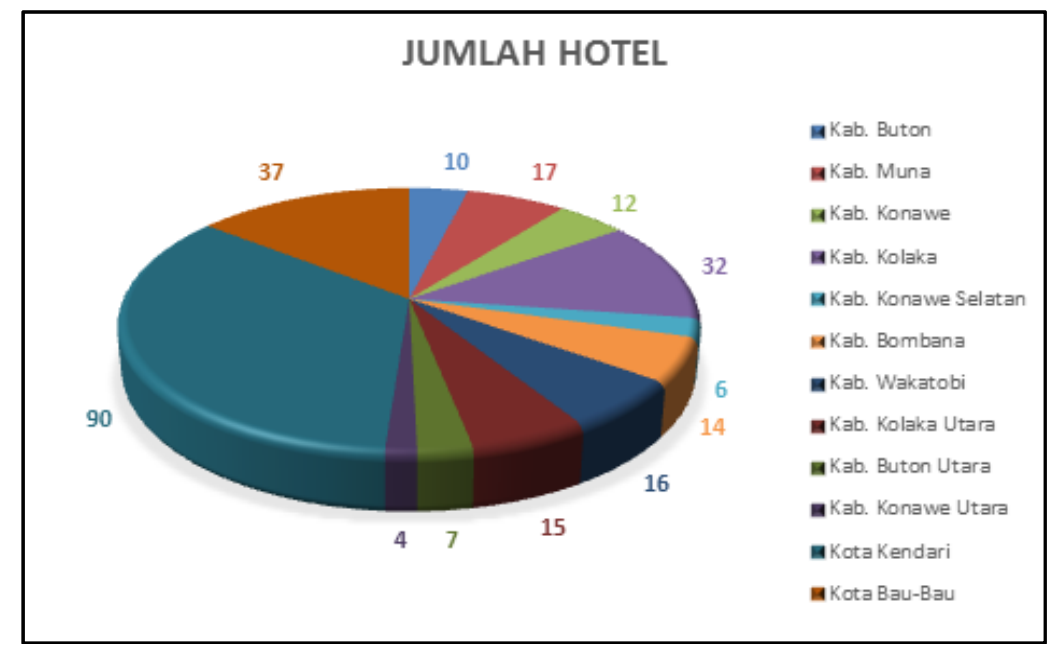

Gambar 3 Jumlah Hotel di Provinsi Sulawesi Tenggara 

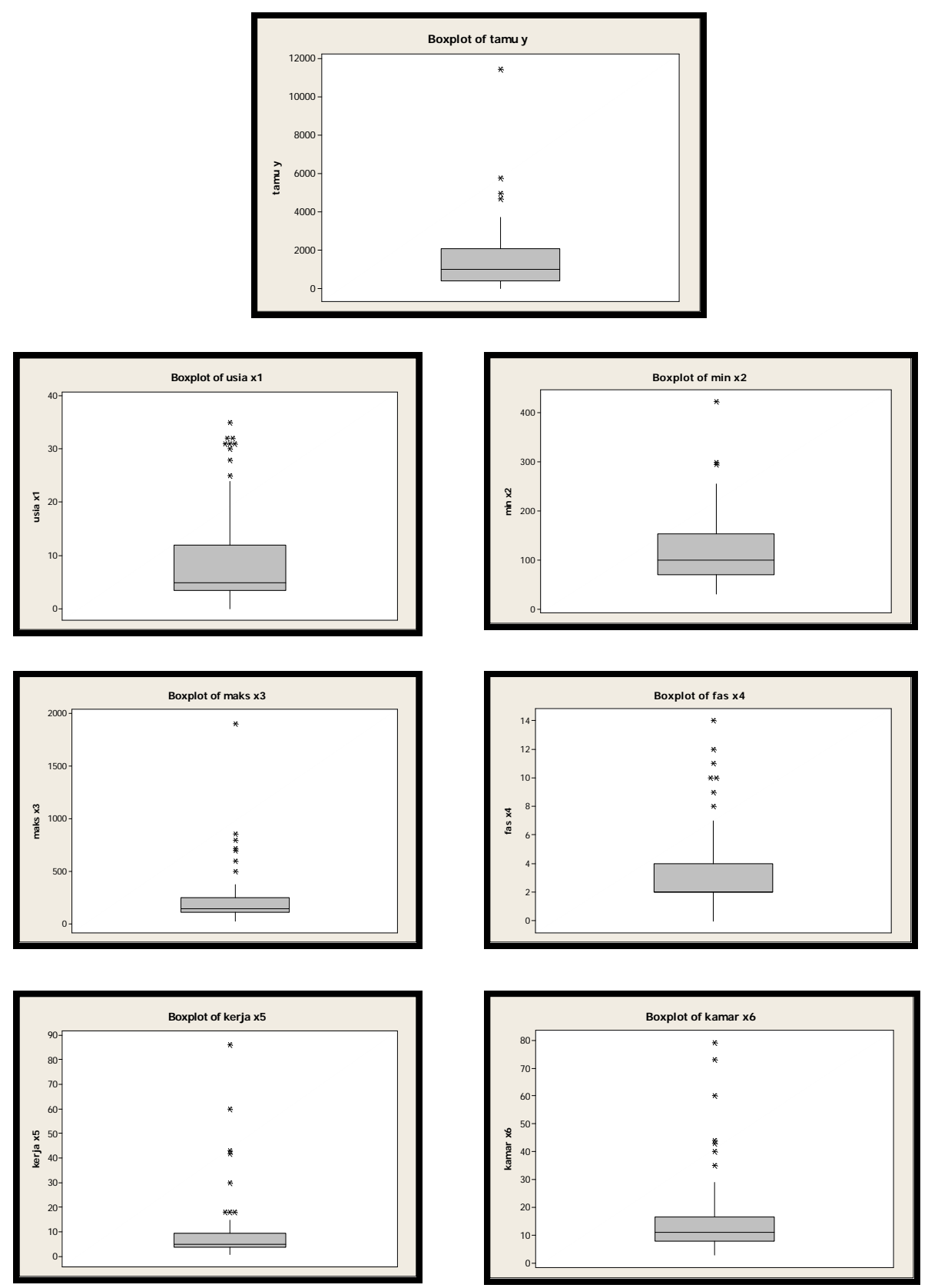

Gambar 4 Boxplot Data Perhotelan

Pada Gambar 3 terdapat jumlah hotel yang terdapat di masing-masing kota atau kabupaten yang ada di Sultra. Terlihat bahwa kota Kendari mempunyai jumlah hotel yang paling banyak. Ada 2 hal yang melatarbelakangi hal ini. Pertama, Kendari adalah ibukota provinsi. Kedua, Kendari merupakan kota yang memiliki jumlah fasilitas dan infrastruktur yang lebih banyak jika dibandingkan dengan kota atau kabupaten lain. Kabupaten Konawe Utara merupakan kota yang mempunyai jumlah hotel paling sedikit karena kabupaten ini merupakan daerah pemekaran yang baru terbentuk pada tahun 2007 sehingga masih dalam tahap pembangunan fasilitas dan infrastruktur di berbagai sektor, termasuk sektor perhotelan. 


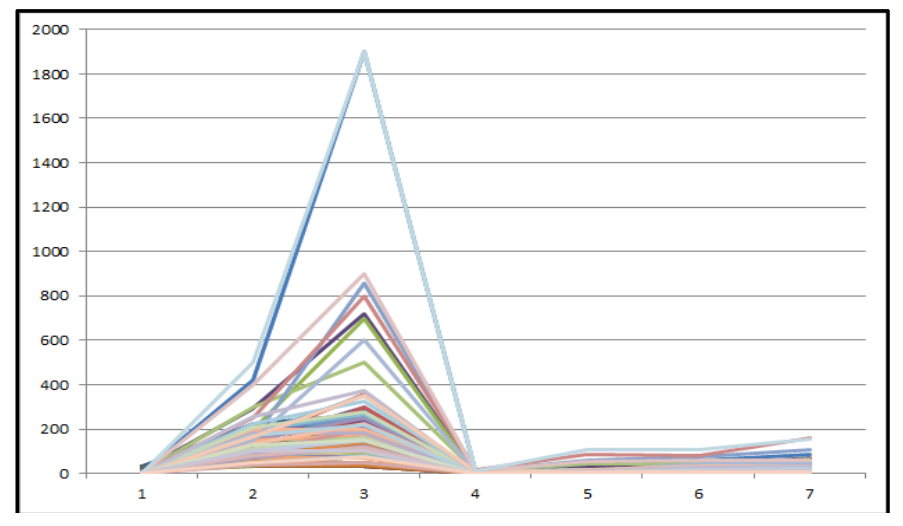

Gambar 5 Chart Sebelum Transformasi Wavelet

Jumlah hotel yang cukup besar di kota Kendari menjadikan persaingan yang cukup tinggi. Hal ini semakin diperkuat dengan wilayah kota Kendari yang tidak terlalu besar semakin mendukung persaingan dalam memperoleh jumlah pengunjung yang banyak. Berbagai faktor dapat menyebabkan jumlah pengunjung di suatu hotel bertambah atau berkurang. Untuk penelitian ini dipilih enam faktor, yaitu usia hotel, tarif minimal, tarif maksimal, jumlah fasilitas yang ada di hotel, jumlah tenaga kerja, jumlah kamar, dan jumlah tempat tidur. Masih terdapat faktor-faktor lain yang dapat digunakan akan tetapi karena kesulitan untuk mendapatkan data atau informasi maka penelitian ini hanya menggunakan 6 faktor yang telah disebutkan.

Outlier pada data perhotelan dapat dilihat pada Gambar 4. Pada gambar tersebut terlihat ada outlier pada setiap variabel. Untuk mengatasi adanya outlier maka dilakukan transformasi wavelet kontinu dengan chart hasil transformasi dapat dilihat pada Gambar 6. Dengan menggunakan enam faktor, dilakukan transformasi wavelet dengan menggunakan Haar wavelet. Adapun skala yang digunakan adalah skala 1-10. Dengan transformasi wavelet, dihasilkan koefisien-koefisien baru. Koefisien-koefisien yang dihasilkan ini selanjutnya akan menjadi nilai-nilai dari variabel bebas yang akan digunakan untuk membentuk model regresi bersama dengan variabel respon jumlah tamu.

Skala 1

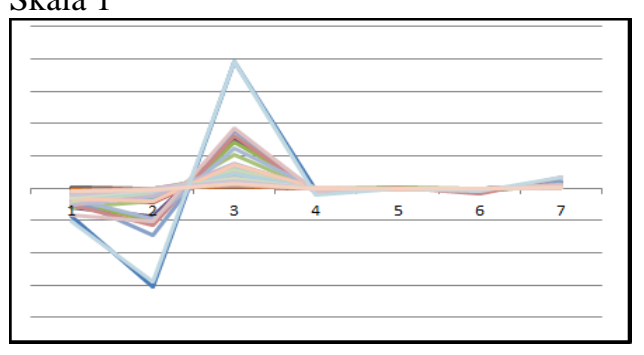

Skala 3

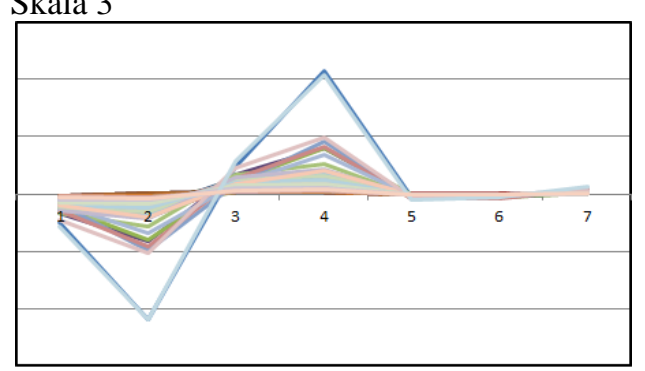

Skala 2

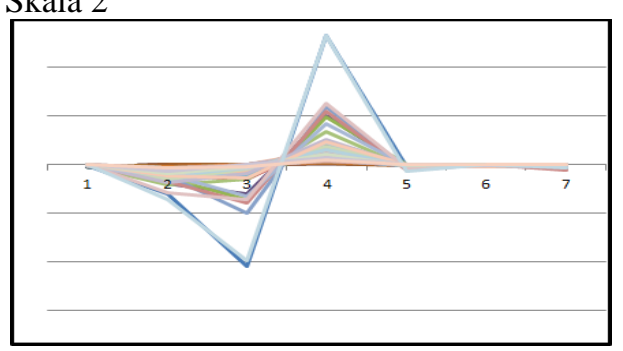

Skala 4

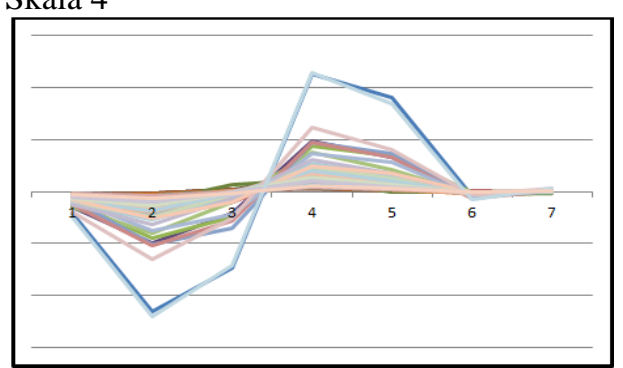


Skala 5

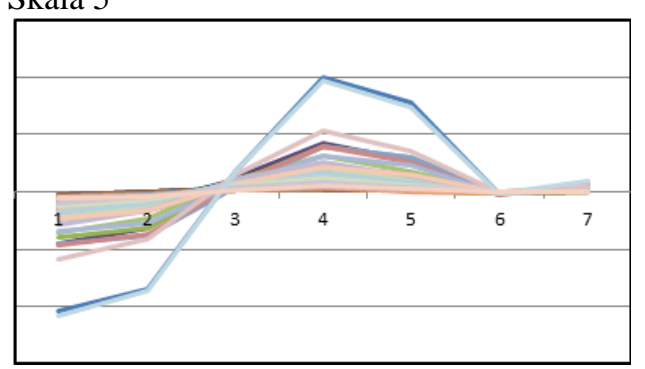

Skala 6

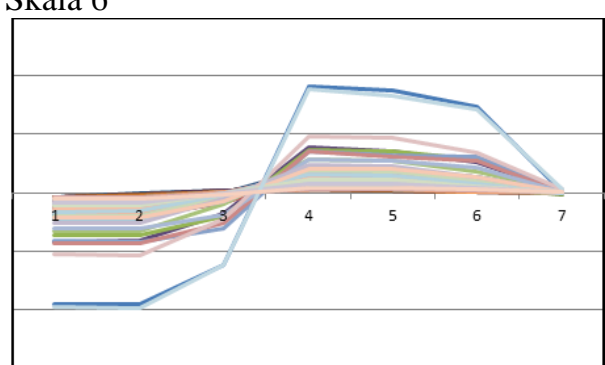

Gambar 6 Chart Hasil Transformasi Wavelet Kontinu

Pada Gambar 5 terdapat chart untuk data sebelum ditansformasi. Terlihat bahwa ada titik-titik yang nilainya cukup jauh dari titik-titik yang lain. Dalam hal ini titik-titik tersebut dikatakan sebagai outlier. Jika dibandingkan dengan Gambar 6a dan 6b terlihat bahwa hasil yang diperoleh tidak terlalu smooth akan tetapi cukup mengecilkan jarak antar titik.

Skala 7

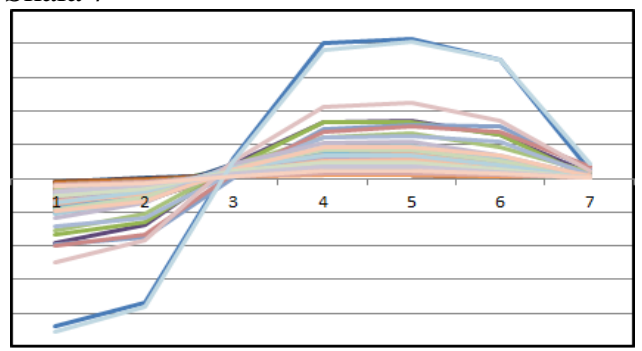

Skala 9

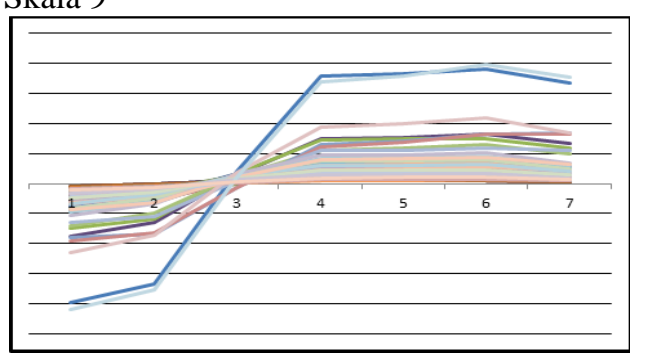

Skala 8

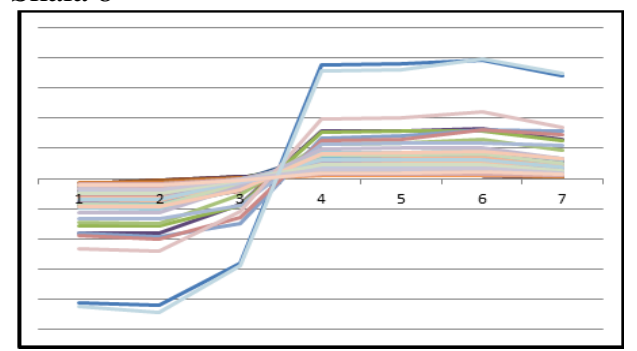

Skala 10

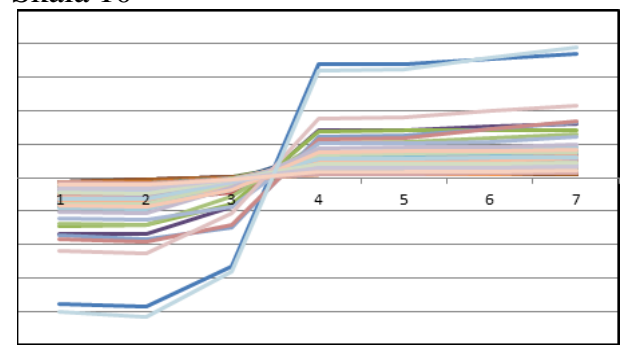

Gambar 7 Chart Hasil Transformasi Wavelet Kontinu

Pada Tabel 3 dan 4 terdapat nilai $\mathrm{R}^{2}$ dan PRESS untuk hasil PLS data transformasi wavelet. Berikut adalah penjelasan jumlah komponen yang akan digunakan.

Tabel 2 Nilai $R^{2}$ dan PRESS untuk Hasil Transformasi

\begin{tabular}{cccccccc}
\hline Skala & $\begin{array}{c}\text { Jumlah } \\
\text { Komponen }\end{array}$ & $\boldsymbol{R}^{\mathbf{2}} \mathbf{( \% )}$ & PRESS & Skala & $\begin{array}{c}\text { Jumlah } \\
\text { Komponen }\end{array}$ & $\begin{array}{c}\text { R2 } \\
\mathbf{( \% )}\end{array}$ & PRESS \\
\hline 1 & 3 & 71,8 & 249696148 & 6 & 2 & 72,3 & 230710653 \\
2 & 4 & 73,6 & 259107687 & 7 & 5 & 73,1 & 270686876 \\
3 & 3 & 73,6 & 244570794 & 8 & 5 & 74 & 262467363 \\
4 & 2 & 72,9 & 241868063 & 9 & 5 & 74,1 & 266047604 \\
5 & 3 & 73,4 & 254319457 & 10 & 5 & 73,7 & 269419312 \\
\hline
\end{tabular}


Tabel 3 Nilai $R^{2}$ dan PRESS Data Hasil Transformasi Wavelet

\begin{tabular}{ccc}
\multicolumn{3}{c}{ Skala 1 } \\
\hline Komponen & $\mathbf{R}^{2}$ & PRESS \\
\hline 1 & 0,614 & 317424528 \\
2 & 0,692 & 285743689 \\
3 & 0,718 & 249696148 \\
4 & 0,736 & 260445552 \\
5 & 0,737 & 264940284 \\
6 & 0,741 & 275947233 \\
7 & 0,742 & 277517420 \\
\hline
\end{tabular}

\begin{tabular}{ccc}
\multicolumn{3}{c}{ Skala 4} \\
\hline Komponen & $\mathbf{R}^{2}$ & PRESS \\
\hline 1 & 0,677 & 252268027 \\
2 & 0,729 & 241868063 \\
3 & 0,737 & 246508827 \\
4 & 0,738 & 246585229 \\
5 & 0,740 & 257199166 \\
6 & 0,741 & 262333642 \\
7 & 0,741 & 275346097 \\
\hline
\end{tabular}

\begin{tabular}{ccc}
\multicolumn{3}{c}{ Skala 2 } \\
\hline Komponen & R $^{2}$ & PRESS \\
\hline 1 & 0,636 & 295208350 \\
2 & 0,697 & 291438804 \\
3 & 0,721 & 259107687 \\
4 & 0,736 & 257961765 \\
5 & 0,736 & 267082229 \\
6 & 0,736 & 261983888 \\
7 & 0,742 & 277517429 \\
\hline
\end{tabular}

\begin{tabular}{ccc}
\multicolumn{3}{c}{ Skala 5 } \\
\hline Komponen & $\mathbf{R}^{2}$ & PRESS \\
\hline 1 & 0,629 & 292465658 \\
2 & 0,707 & 275321016 \\
3 & 0,734 & 254319457 \\
4 & 0,734 & 260098842 \\
5 & 0,735 & 264457479 \\
6 & 0,737 & 276567641 \\
7 & 0,742 & 277517420 \\
\hline
\end{tabular}

Skala 3

\begin{tabular}{ccc}
\hline Komponen & $\mathbf{R}^{\mathbf{2}}$ & PRESS \\
\hline 1 & 0,627 & 294455305 \\
2 & 0,706 & 272084768 \\
3 & 0,736 & 244570794 \\
4 & 0,737 & 247023559 \\
5 & 0,738 & 257478805 \\
6 & 0,740 & 261341306 \\
7 & 0,742 & 277517420 \\
\hline
\end{tabular}

\begin{tabular}{ccc}
\multicolumn{3}{c}{ Skala 6 } \\
\hline Komponen & $\mathbf{R}^{2}$ & PRESS \\
\hline 1 & 0,673 & 254889778 \\
2 & 0,723 & 230710653 \\
3 & 0,736 & 240243205 \\
4 & 0,736 & 259576519 \\
5 & 0,736 & 270799903 \\
6 & 0,738 & 278631283 \\
7 & 0,742 & 277517420 \\
\hline
\end{tabular}

Tabel 4 Nilai R^2 dan PRESS Data Hasil Transformasi Wavelet

\begin{tabular}{ccc}
\multicolumn{3}{c}{ Skala 7} \\
\hline Komponen & $\mathbf{R}^{2}$ & PRESS \\
\hline 1 & 0,638 & 281706146 \\
2 & 0,673 & 281723450 \\
3 & 0,674 & 294966355 \\
4 & 0,716 & 272545499 \\
5 & 0,731 & 270686876 \\
6 & 0,732 & 283168543 \\
7 & 0,742 & 277517420 \\
\hline
\end{tabular}

\begin{tabular}{ccc}
\multicolumn{3}{c}{ Skala 9 } \\
\hline Komponen & $\mathbf{R}^{2}$ & PRESS \\
\hline 1 & 0,625 & 293594499 \\
2 & 0,651 & 289270553 \\
3 & 0,667 & 303253812 \\
4 & 0,717 & 275005629 \\
5 & 0,741 & 266047604 \\
6 & 0,741 & 267262742 \\
7 & 0,742 & 277517420 \\
\hline
\end{tabular}

\begin{tabular}{ccc}
\multicolumn{3}{c}{ Skala 8 } \\
\hline Komponen & $\mathbf{R}^{2}$ & PRESS \\
\hline 1 & 0,633 & 286959226 \\
2 & 0,650 & 290925584 \\
3 & 0,669 & 305082369 \\
4 & 0,726 & 269277517 \\
5 & 0,740 & 262467363 \\
6 & 0,742 & 276927854 \\
7 & 0,742 & 277517420 \\
\hline
\end{tabular}

\begin{tabular}{ccc}
\multicolumn{3}{c}{ Skala 10 } \\
\hline Komponen & $\mathbf{R}^{2}$ & PRESS \\
\hline 1 & 0,634 & 285598539 \\
2 & 0,652 & 292598094 \\
3 & 0,665 & 309848110 \\
4 & 0,723 & 303858248 \\
5 & 0,737 & 269419312 \\
6 & 0,742 & 277498923 \\
7 & 0,742 & 277517420 \\
\hline
\end{tabular}


Kriteria yang digunakan untuk menentukan jumlah komponen adalah dengan memilih jumlah komponen yang memiliki PRESS terkecil. Pada data hasil transformasi dengan skala 1 digunakan 3 komponen, skala 2 digunakan 4 komponen, skala 3 digunakan 3 komponen, skala 4 digunakan 2 komponen, skala 5 digunakan 3 komponen, skala 6 digunakan 2 komponen, skala 7 digunakan 5 komponen, skala 8 digunakan 5 komponen, skala 9 digunakan 5 komponen, dan skala 10 digunakan 5 komponen. Hasil lengkap dapat dilihat pada Tabel 2.

Langkah selanjutnya adalah memilih hasil yang bersesuaian dengan skala yang akan digunakan. Jika dilihat dari Gambar 6 dan 7 maka akan membingungkan secara visual sebab pola hasil transformasi tidak terlalu sesuai dengan pola asli akan tetapi sudah smooth. Berdasarkan hal ini maka dilakukan perbandingan PRESS yang diperoleh oleh masing-masing komponen yang dihasilkan oleh tiap skala. Jika dilihat pada Tabel 2 maka dipilih skala 6.

Dengan menggunakan skala 6, diperoleh model regresi sebagai berikut.

$$
\begin{aligned}
& \text {-11,492-1,415 Usia-1,494 Tarif Minimal } \\
& \text {-3,440 Tarif Maksimal +1,123 Fasilitas +1,090 Tenaga Kerja } \\
& \text { +2,113 Jumlah Kamar + 219,596 Jumlah Tempat Tidur }
\end{aligned}
$$

Model ini mempunyai nilai $R^{2}$ yang sudah lebih baik jika dibandingkan dengan model yang diperoleh dengan menggunakan transformasi logaritma natural, yaitu 30\%. Walaupun demikian ada kekurangan dari model yang dihasilkan ini, yaitu residual yang diperoleh belum memenuhi asumsi normalitas.

\section{SIMPULAN}

Berikut adalah kesimpulan yang diperoleh mengenai penelitian yang dilakukan. Pertama, model regresi yang diperoleh sudah memenuhi asumsi multikolinear akan tetapi belum memenuhi asumsi normalitas. Kedua, secara visual, titik yang dianggap sebagai outlier menjadi lebih dekat jaraknya dengan titik-titik yang lain setelah ditransformasi wavelet. Untuk penelitian selanjutnya disarankan untuk menggunakan mother wavelet yang lebih sesuai dengan data. Selain itu, melanjutkan pembentukan model sampai pengujian keberartian koefisien model.

\section{DAFTAR PUSTAKA}

Abdi, H. (2003). Partial Least Squares (KTP) Regression. Encyclopedia of Social Sciences Research Methods (online), 1-7. Diakses dari www.utdallas.edu/ herve.

Addison, P. (2002). The Illustrated Wavelet Transform Handbook. Institute of Physics Publishing, London.

Antoniadis, A., Bigos, J., dan Sapatinas, T. (2001). Wavelet Estimators in Nonparametric Regression: A Comparative Simulation Study. Journal of Statistical Software, 6, hal. 1-83.

Biro Humas Pemerintahan Provinsi Sulawesi Tenggara. (2012). Profil Sultra. 
Boulesteix, A., Strimmer, K. (2006). Partial Least Squares: A Versatile Tool For The Analysis Of High-Dimensional Genomic Data. Diakses dari http://www.slcmsr.net/boulesteix/papers/review

Chen, D., Hu, B., X, Shao., Qingde, S. (2004). Variable Selection by Modified IPW (Iterative Predictor Weighting)-KTP (Partial Least Squares) in Continuous Wavelet Regression Models. The Analyst. Diakses dari www.rsc.org/analyst.

Derquenne, C. (1993). Outlier detection before running statistical methods. Theory of Probability and its Applications, 37(2), 323-4. doi:10.1137/1137066.

Daubechies, I. (1992). Ten Lectures on Wavelets. CBMS-NSF Regional Conference Series in Applied Mathematics, 61, Philadelphia, PA: SIAM.

Garthwaite, P. H. (1994). An Interpretation of Partial Least Squares. Journal of the American Statistical Association, 89: 122-127.

Investor Daily Indonesia. (2012). Pertumbuhan Ekonomi Sultra Lampaui Nasional. Diakses dari http://www.investor.co.id/home/pertumbuhan-ekonomi-sultra-lampaui-nasional/28618

Katalog BPS. (2011). Direktori dan Tingkat Penghunian Kamar Hotel Provinsi Sulawesi Tenggara Tahun 2011. Kendari: Badan Pusat Statistik Provinsi Sulawesi Tenggara.

Lang, W. C., Forinash, K. (1998). Time-Frequency Analysis with the Continuous Wavelet Transform. Am. J. Phys, 66, 794-797.

Media Sultra. (2011). Sektor Perhotelan Sultra Serap 8791 Tenaga Kerja. Diakses dari http://sindikasi.inilah.com/read/detail/1812732/sektor-perhotelan-sultra-serap-8791-tenagakerja.

Murguia, J. S., Campos-Canton, E. (2005). Wavelet Analysis of Chaotic Time Series. Revista Mexicana De Fisica, 52(2), 155-162.

Naes, T., Isaksson, T., Fearn, T., dan Davies, T. (2002). Multivariate Calibration and Classification. Chichester: NIR Publications.

Zhu, C., Kitagawa, H., Papadimitriou, S., Faloutsos, C. (2011). Outlier detection by example. Journal of Intelligent Information Systems, 36(2), 217-247. doi:10.1007/s10844-010-0128-1. 